\title{
PROFIT ANALYSIS OF CABBAGE FARM MANAGEMENT IN MALANG, INDONESIA
}

\author{
Haryati Novi, Dewi Heptari Elita, Rachmawati Nani Dwi \\ Department of Agricultural Social Economics, Faculty of Agriculture, \\ University of Brawijaya, Indonesia \\ *E-mail: noviharyati@ub.ac.id
}

\begin{abstract}
The successful agribusiness is based on farmer competency and their ability to make farming decisions. This research aims to understand: the characteristic of cabbage farmer; the revenue analysis and feasibility study of cabbage farming; the obstacles and the risks which are encountered by the farmer. Malang was chosen deliberately as the research location considering it as the centre of cabbage production. This research used a probability sampling, with 24 samples of respondent drew by a simple random sampling. Result shows that the majority of respondent are between 30-49 years old and most of them are elementary school graduates. Most farmers have worked on their farming for more than 20 30 years. Some of respondent has wide area of cabbage farming from 1-2 ha, that makes the farming profits obtained was Rp. 22,488,325. Result shows that RC Ratio were 2,16, BEP price is Rp. $1.174,39$, and BEP unit is $2.811,19 \mathrm{~kg}$. It can be concluded that cabbage farming was done during that season was highly feasible.
\end{abstract}

\section{KEY WORDS}

Profit analysis, risk, cabbage farming.

The success of farm management activities is highly dependent on the competency of farmers as the main manager. The competency of farmers is not the same as the others, it really depends on the characteristics they have. There are many factors that relate to farmers who improve them in increasing the quantity and quality of their products. These factors are age, education level, farming experience, family size, cropping pattern, and land ownership. Age factor becomes one that is not important in the characteristics of farmers in terms of increasing the number of farmers, will further enhance the experience in farming, this will further improve the competency of farmers in obtaining farms (Mulyasa, 2003).

Education greatly determines the level of competency of farmers in conducting farm management. This is because basically education describes the level of ability and level of understanding of farmers regarding everything, both increasing knowledge, skills, and changing attitudes of farmers. In addition, the factor of land area cultivated by farmers is very closely related to farmers' income. Lionberger in Andawan (2007) explained that the wider the land controlled by farmers, usually farmers has a quick attitude to adopt innovation because they have better economic capabilities.

Farm Management experience plays an important role in increasing farmers' competencies. Experience is education that is obtained by someone in the routine of daily life, such as events or realities that they experience. The purpose of this study of cabbage farm management in Malang can be divided as follows: (1) To find out the characteristics of cabbage farmers in Malang, (2) can analyze cabbage farming income in Malang, (3) To find out the feasibility analysis $f$ cabbage farming in Malang, (4) understanding the obstacles and risks faced by cabbage farmers in Malang.

\section{LITERATURE REVIEW}

According to Darmawi (2004) risk can be defined into several meanings, such as risk as a possibility of loss, risk which is uncertainty, risk is the spread of actual results from expected results and risk as the probability of an outcome different from the expected results. Farming activities carried out by farmers are always faced with situations of risk and 
uncertainty where the size of the risk experienced by a farmer depends on the courage to make a decision (Rodjak, 2002).

Facing the risk, cabbage farmers can behave bravely, neutral and reluctant to risk (Kadarsan, 1995). Basically, no farmer dares to take risks without expecting greater results. According to Soekartawi et al (1993), farmer's behavior towards risk depends on the attitudes and behavior of individuals who are also influenced by the environment. Socio-economic factors such as age, education and farming experience and other social factors can influence farmers' behaviors in facing risks.

Based on the results of Aini's (2015) research conducted, it can be concluded that the productivity and income of cabbage farming in rainfed lowland areas is greater than the productivity and income of cabbage farming on dry land. The risk of cabbage farming on dry land is greater than the risk in rainfed lowland, where the risk of cabbage farming is caused by weather and pest disease. On dry land 93.18 percent of farmers behave in a neutral manner and 6.82 percent behave reluctantly on risk, whereas in rainfed lowland areas 41.94 percent farmers behave in a neutral manner and 58.06 percent of farmers behave reluctantly to risk, and not found by farmers who behave bravely towards risk on dry land and in rainfed lowland areas. Farmer's behavior towards the risk of cabbage farming in dry land and rainfed lowland is influenced by farm income, land area, farmer's age, number of family dependents, and type of land.

\section{METHODS OF RESEARCH}

This research was conducted in June-December 2018 in Malang. The research location was chosen intentionally, based on the consideration that it was one of the regency in East Java which was the center of cabbage production.

The sampling technique used is probability sampling with a simple random side method. The sample used amounted to 24 research respondents. The type of data used in this study is primary data obtained through interviews with cabbage farmers.

Data analysis is carried out quantitatively for income and profit analysis, while qualitatively descriptive used frequency tables for risk analysis and farmer perceptions.

\section{RESULTS AND DISCUSSION}

Characteristics of cabbage farmers studied included age, education level, main and side jobs, number of families, length of cultivation, and land ownership can be seen in Tables 1-8:

Table 1 - Characteristics of Respondents Based on Age Level

\begin{tabular}{cccc}
\hline Category & Age (Year) & Quantity (persons) & Percentage (\%) \\
\hline Young & $30-49$ & 13 & 52 \\
Average & $50-69$ & 11 & 44 \\
Old & $70-89$ & 1 & 4 \\
\hline & Number & 24 & 100 \\
\hline
\end{tabular}

Source: Primary Data (processed), 2018.

Based on Table 1 shows that the highest number of respondents is in the young category, 30 - 49 years, as many as 13 persons with a percentage of $52 \%$. This can affect the level of productivity of cabbage, apart from the physical young farmers who are far better than the old farmers; young farmers also tend to have more curiosity and enthusiasm to develop their farm management with adoption and new technological innovations. This is in accordance with Arlis (2016) statement, that farmers who are easily aged have a stronger physical and high enthusiasm to work, and also a statement by Soekartawi (2002), that the younger age farmers usually have the enthusiasm to want to know what they have not know, so that they are trying to more quickly adopt an innovation, even though they are not experienced in the matter of adopting the innovation. 
Table 2 - Characteristic of Respondents Based on Education Level

\begin{tabular}{ccc}
\hline Education Level & Quantity (Persons) & Percentage (\%) \\
\hline Elementary School & 14 & 58 \\
Junior High School & 4 & 17 \\
Senior High School & 6 & 25 \\
\hline Total & 24 & 100 \\
\hline
\end{tabular}

Source: Primary Data (processed), 2018.

Table 2 shows that the highest number of respondents had an elementary school education level of 14 persons with a percentage of $58 \%$. The level of education influences farmers' decisions both in farm management and daily life. If the farmer's education level is low, it will influence farmers 'decisions in adopting new technologies that can increase farmers' income. This is in accordance with the statement of Mardikanto (2009) that education is the process of developing one's knowledge and attitudes that are carried out in a planned manner, which will form an insight into an object that will eventually lead to decision making.

Table 3 - Characteristic of Respondents Based on Main Occupation

\begin{tabular}{ccc}
\hline Main Occupation & Quantity (Persons) & Percentage (\%) \\
\hline Farmer & 23 & 96 \\
Land owner & 1 & 4 \\
\hline Total & 24 & 100 \\
\hline
\end{tabular}

Source: Primary Data (processed by Researcher), 2018.

Table 4 - Characteristic of Respondents Based on Side Occupation

\begin{tabular}{ccc}
\hline Side Job & Quantity (persons) & Percentage $(\%)$ \\
\hline Farmer with no side job & 13 & 54 \\
Seller & 7 & 30 \\
Entrepreneur & 1 & 4 \\
Security & 1 & 4 \\
Gardener & 1 & 4 \\
Farmer & 1 & 4 \\
\hline Number & 24 & 100 \\
\hline
\end{tabular}

Source: Primary Data (processed by Researcher), 2018.

Based on Table 3 and Table 4, it can be seen that most of the respondents made farmers as their main jobs are 23 persons with a percentage of $96 \%$. Even though the work on the farm does not require farmers to be on their farm every day, as Dewi (2018) stated, farmers can use their free time by working in other sectors if they still want to increase income, most respondents are 13 persons with $54 \%$ not have side jobs and as many as 11 people or $46 \%$ have side jobs outside the agricultural sector.

Table 5 shows that the number of families of respondents consisted of 2 to more than 6 people. More and more families can also benefit losses. The advantage is because it has more amount of energy to help farm management, but as a loss because there will be more family expenses. This is in accordance with the statement of Shamsiah (2002), that the higher the family burden, the higher the production that needs to be produced to meet family needs in order to achieve prosperity and the more family members, the greater the opportunity for family members to assist in farm management activities to reduce labour costs.

Table 5 - Characteristic of Respondents Based on Family Members

\begin{tabular}{ccc}
\hline Family Members & Quantity (Persons) & Percentage (\%) \\
\hline $2-4$ persons & 13 & 54 \\
$5-6$ persons & 9 & 38 \\
$>6$ persons & 2 & 8 \\
\hline Number & 24 & 100
\end{tabular}

Source: Primary Data (processed), 2018. 
Table 6 - Characteristic of Respondents Based on Farming Management Length

\begin{tabular}{ccc}
\hline Farm Management Length & Quantity (persons) & Percentage (\%) \\
\hline $0-30$ years & 4 & 17 \\
31 years & 19 & 79 \\
40 years & 1 & 4 \\
\hline Number & 24 & 100 \\
\hline
\end{tabular}

Source: Primary Data (processed), 2018.

The characteristics of farmers regarding the duration of farm management are shown in Table 6, most of the respondents had experience of 31 years as many as 19 persons, while those with longer experience were only 1 person, other respondents had less than 30 years of experience. Seeing from the farming experience carried out by 24 respondents, it can be said that the experience is quite good and long in farming the farmers are able to obtain knowledge that is not learned in school (Arlis, 2016).

Table 7 - Characteristic of Respondents Based on Cropping System

\begin{tabular}{ccc}
\hline Planting System & Quantity (persons) & Percentage (\%) \\
\hline Monoculture & 18 & 75 \\
Polyculture & 5 & 21 \\
Cropping Rotation & 1 & 4 \\
\hline Number & 24 & 100 \\
\hline
\end{tabular}

Source: Primary Data (processed), 2018.

Table 7 shows the planting system used by respondents. Based on the results of interviews there are 3 types, namely monoculture, polyculture, and cropping rotation. The majority of respondents used a monoculture planting system that is as many as 18 people with a percentage of $75 \%$. The monoculture planting system on cabbage commodities has a spacing of $30 \times 75 \mathrm{~cm}$. The monoculture cropping system is considered more effective because it facilitates maintenance of commodities that are planted and only plants one type of crop, so the treatment will be more intensive. In addition, according to Anwar (2012), the monoculture cropping pattern received by plants will be more optimally utilized compared to the polyculture cropping pattern. Thus, the monoculture planting pattern is considered to be in accordance with the cropping pattern on cabbage commodities.

Table 8 - Characteristic of Respondents Based on Land Usage

\begin{tabular}{ccc}
\hline Farm Management Length & Quantity (persons) & Percentage (\%) \\
\hline One's own & 14 & 58 \\
Hiring & 6 & 25 \\
One's own and Hiring & 4 & 17 \\
\hline Number & 24 & 100 \\
\hline
\end{tabular}

Source: Primary Data (processed), 2018.

Table 8 shows that respondents use more of their own land as many as 14 people with a percentage of $58 \%$. Based on the results of interviews in the field, it is known that the average area of land used by farmers is $0.75 \mathrm{Ha}$. The land area is included in the medium category (Soekartawi, 2002). Then, respondent farmers are grouped in medium farmers, this is in accordance with the statement of Sastraatmadja (2010), that small farmers are farmers who have 0.50 up to 1 hectare land.

The purpose of doing farming is to get the maximum revenue by reducing expenditure so that farmers will get high net income. In this study, the average land area of $0.75 \mathrm{Ha}$ was able to produce cabbage of $8,876 \mathrm{Kg}$ with an average selling price of $\mathrm{Rp}$. 3,708. Details of receipts, costs, and profits of cabbage farm management can be seen in table 9 .

Table 9 shows that cabbage farm management in Malang takes profit because it has a higher value than the total cost. The total profit or average income of cabbage farm management for the average land area of 0,75 ha is Rp. $22,488,325$. 
Table 9 - Revenue, Cost, Cabbage Farm Management Profit in Malang

\begin{tabular}{lll}
\hline No. & Description & Average \\
\hline 1. & Revenue & $\operatorname{Rp~32,912,208}$ \\
2. & Hiring Cost & $\operatorname{Rp~1,877,556}$ \\
3. & Deprecation Cost & $\operatorname{Rp~342,783}$ \\
4. & Seed Cost & $\operatorname{Rp~1,539,083~}$ \\
5. & Fertilizer Cost & $\operatorname{Rp~3,020,940}$ \\
6. & Medicine Cost & $\operatorname{Rp~1,130,786}$ \\
7. & Labor Cost & $\operatorname{Rp~2,512,735}$ \\
\hline Cost Total & & $\operatorname{Rp~10,423,883~}$ \\
\hline Profit & & $R p 22,488,325$ \\
\hline
\end{tabular}

Source: Primary Data (processed), 2018.

Farming feasibility can be calculated using the ratio of revenue to costs or $\mathrm{R} / \mathrm{C}$ ratio. Based on the results of the study, obtained the feasibility level of cabbage farm management as follows:

$$
R / C=T R / T C==2.16
$$

It means the ratio between total revenue and the total cost obtained is 2.16 . This shows that the cabbage farm management that is run can be said to be feasible because it has an RC Ratio of more than 1, where each farmer issues an input of Rp. 1 will get revenue of Rp. 2.16.

In addition to carrying out RC Ratio analysis, to find out whether the farm management is feasible or not, it can be calculated by the break-even point or BEP of the business being carried out. Based on the results of the study, BEP calculation results are obtained as follows:

$$
\begin{gathered}
B E P_{\text {harga }}=T C / Q=\operatorname{Rp} 1.174,39 \\
B E P_{\text {unit }}=T C / P=2,811.19 \mathrm{Kg} \\
B E P_{\text {revenue }}=B E P_{\text {price }} \times B E P_{\text {unit }}=\operatorname{Rp} 3,301,429.57
\end{gathered}
$$

Based on the results of calculations, it can be seen that if cabbage farm management breaks even should be sold at a price of IDR $1,174.39$ with a quantity of $2,811.19 \mathrm{Kg}$. When compared with the average number of cabbage sold and the price used, the cabbage farming that is run can be said to be feasible because it has broken even or is able to return the initial capital. The actual receipt obtained by the farmer, which is Rp. 32,912,208, has passed the break-even point or BEP of receipt, so that the farming run can be considered feasible.

When carrying out cabbage farm management activities, it is certainly inseparable from various obstacles that will be faced by farmers. Cabbage farmers in Malang mentioned a number of obstacles faced, namely pest attacks (Plant Pest Organisms), fluctuating prices, capital, and climate. Climate change and climate variability have an impact in the form of fluctuations in temperature and humidity that can increase the growth and development of pests.

Capital has a significant impact on financing agricultural production. In addition to capital, the lack of capital is accompanied by the low quality of farmers' human resources, which include low levels of education, skills, and mastery of technology, weak motivation to develop and defend their rights, and lack of leadership among the farmers themselves (Sesbany , 2011).

The risk experienced by farmers is divided into 5 namely, production risk, market risk or price, institutional risk, financial risk, and human risk. The production risks experienced by respondents were attacks on pests, climate and natural disasters. This is in accordance with 
the opinion of Harwood, et al (1999) in Rio Saputra (2017) that the risk of production in agriculture can be caused due to uncontrolled events. Usually caused by extreme natural conditions such as rainfall, climate, weather, and attacks of pests and diseases. The biggest production risk experienced by farmers is pest attack which is as many as 15 people or $56 \%$.

Market risk or price faced by farmers is divided into three, namely, fluctuating selling prices of cabbage, reduced demand, and expensive input prices. The risk most faced by farmers is the selling price of a fluent cabbage of 17 people or by $47 \%$. Fluctuating prices are felt by farmers because farmers do not have market price certainty regarding the selling price of products. This is in accordance with the opinion of Harwood, et al (1999) in Saputra (2017) that price risk can be influenced by changes in the selling price of products that will always fluctuate. In addition, fluctuations in input prices and agricultural output can affect production costs. Institutional risks experienced by farmers are lack of agricultural counseling, government policies that do not favor farmers or small people, and the slow development or facilitation of agriculture such as irrigation, roads and warehouses. The most risk faced by farmers was the absence of 11 agricultural extension agents who provided counseling in related villages.

According to Harwood et al (1999) in Saputra (2017), institutions or institutions affect agricultural products through counseling, policies and regulations. The presence of extension agents has a big influence on farmers' knowledge of policies, programs and incentives provided by the government related to farm management activities carried out by farmers. Financial risk on cabbage farming experienced by farmers is a lack of farming capital, lack of cooperatives, and large household expenditure. Harwood et al (1999) in Saputra (2017) states that financial risk is an impact caused by the way farmers manage their finances. The most common risk faced by the respondent farmers is the lack of social capital as many as 13 people. Owned capital can be used optimally to produce output. Many capital loans made by farmers provide balanced benefits in the form of profits between managers and capital owners.

Human risk that can be experienced by cabbage farmers is damage to equipment due to continuous use, loss of equipment due to being stolen or affected by fire, and the health of farmers who are disturbed. The biggest risk faced by farmers is damage to production equipment and loss of equipment due to being stolen or burned, each numbering 9 people. This risk is caused by human behavior in carrying out the production process. Human resources need to be considered to produce optimal output. Human activities such as negligence can cause losses such as negligence which results in fire, theft and damage to production facilities (Harwood, et al (1999) in Saputra (2017)).

The overall risks of production, markets, institutions, finance and people have different proportions for cabbage farmers. the risk most faced by farmers is the risk that comes from activities originating from the market while the least risk faced by farmers is the risk that comes from the institution. Market risk related to fluctuating selling prices in the market or fluctuating is the most problem because Cabbage is a highly volatile agricultural commodity in terms of production and prices at the farm level. Cabbage production can be abundant at one time so the price becomes very cheap. Meanwhile, farmers' concerns about the risks of farm management at other times lead to reduced production, which increases prices (Food Crop Agriculture Service, 2007).

According to respondent, the risks most often faced are all things that can cause losses to vegetable farm management and the consequences that become a burden on farmers if they do vegetable farming, such as input, output, production facilities, and so on. According to Abdurrahman (2009) opinion that the risk of cabbage farming is quite high both from the attack of plant pests and fluctuating prices. This shows that in conducting cabbage farming, farmers consider that pest attacks, price problems and others are consequences that must be borne by farmers.

The most common failure in cabbage farming is the damage to vegetables due to pests and diseases as many as 17 perceptions. This is consistent with Naylor's statement in Abdurrahman (2009) that seasonal crops with horticulture types have a greater risk of failure due to the growth and development of pests and diseases of plant / pest organisms (OPT). 
The level of productivity risk in this study is divided into three, namely less than $20 \%$, $20 \%-65 \%$, and more than $65 \%$. According to farmers' perceptions, at most the level of risk faced by farmers is greater than $65 \%$, with 14 perceptions. Then, farmers' perceptions of uneven land risk also show that farmers can still tolerate land irregularities by taking various precautions.

The way farmers deal with risk is divided into three, namely, before the occurrence of risk, when the risk occurs during the production period, and after experiencing risks. Before the risk occurred, farmers made more preparations for all supporting factors for cabbage farm management production such as land management and irrigation. When there is a risk in the production period, the most that farmers do is to control pests using pesticides, while the other way is to use fertilizer. The use of pesticides is an option if other methods of control have been tried and do not reveal satisfactory results and can be done if the pest population has reached the economic threshold (Hanindipto, 2008).

When the risk has occurred, the way farmers handle it the most is to continue farm management until the harvest period even though vegetable production is not as expected, while the least method is done by finding a solution by asking the local agriculture instructor about how to deal with the risks. From the overall way farmers deal with risk, most farmers deal with risks at the time of risk. This is because farmers experience a lack of capital in minimizing the risk that might arise. In accordance with Saptana's opinion (2011), that if the farmer's income is large enough, they can carry out various strategies to reduce the risks they face and conversely the limitations of farmers such as capital can be an obstacle for farmers to reduce risk.

\section{CONCLUSION}

Cabbage farmer done during the time of the research in Malang considered as highly feasible. It can be seen from the result from total cost of Rp. 10,423,833 with total revenues of Rp. 32,912,208. The profits obtained are Rp. 22,488,325. Cabbage farm management is feasible because it has an $\mathrm{R} / \mathrm{C}$ ratio of 2.16 , and is sold at a price that exceeds the BEP price Rp. 1,174.39. Moreover, the quantity that is produced by farmers are exceeds the BEP unit $(2,811.19 \mathrm{Kg})$. The successful of the business was related mostly of the farmer experiences. Although they are between 31-60 years old and elementary school graduates, they are already within the business for more than 30 years. They also have stable area for farming and focusing on cabbage around 0,75 to more than 1 ha. However, cabbage farmer has some constraints, such as plant diseases and pest, fluctuating price, and climate. Most cabbage farmers spraying pesticides to eradicate pests and diseases. In this way, the highly successful business still not yet consider safety environment as important factor to sustainable agriculture.

\section{REFERENCES}

1. Aini, H.N, Prasmatiwi, F.E and Sayekti, W.D. 2015. Analisis Pendapatan and Risiko Usahatani Kubis Pada Lahan Kering and Lahan Sawah Tadah Hujan Di Kecamatan Gisting Kabupaten Tanggamus. JIAA, Vol. 3(1).

2. Arlis Dewi Kuraesin. 2016. Influence Organizational Structure on the Quality of Accounting Information Systems. Research Journal of Financial and Accounting. 7(2). pp. 1-10.

3. Darmawi H. 2004. Manajemen Risiko. Bumi Aksara. Jakarta

4. Departemen Pertanian. 2007. Rekomendasi Pemupukan N, P and K pada Padi SawahSpesifik Lokasi. Peraturan Menteri Pertanian Nomor 40/Permentan/OT.140/04/2007. Departemen Pertanian, Jakarta.

5. Hanindipto, W.B.D. 2008. Kajian Penggunaan Pestisida Terhadap Kemampuan Lingkungan di Kabupaten Dati II Klaten; Mata Kuliah Hukum Lingkungan Program Studi Ilmu Lingkungan; Program Pasca Sarjana UGM. Yogyakarta (ID). UGM Press.

6. Harwood, J., Heifner, R., Coble, K., Perry, J., and Agapi, S. 1999. Managing Risk in 
Farming Concepts, Research, and Analysis. Agricultural Economic Report no. 774. US Department of Agriculture. p. 130.

7. Kadarsan H.W. 1995. Keuangan Pertanian and Pembiayaan perusahaan Agribisnis. Gramedia Pustaka Utama. Jakarta.

8. Lionberger, H. F and P. H. Gwin. 1982. Communication Strategies: A Guide For Agricultural Change Agents. Danville (US). The Interestate Printers \& Publisher, Inc.

9. Mardikanto, Totok, 2009. Sistem Penyuluhan Pertanian. Surakarta (ID). UNS Press

10. Mulyasa. E. 2003. Kurikulum Berbasis Kompetens; Konsep, Karakteristik and Implementasi. Bandung. PT Remaja Rosda Karya.

11. Rodjak, A. 2002. Manajemen Usahatani. Penerbit Pustaka Giratuna. Bandung

12. Saptana, Daryanto, A., Daryanto, H., and Kunjtoro. 2011. Analisis Efisiensi Produksi Komoditas Cabai Merah Besar and Cabai Merah Keriting. Forum Pascasarjana [internet]. [diunduh 13 Januari 2019]; 34(3): 173-183. Tersedia dari: http://download.garuda.ristekdikti.go.id/article.php?article=86280\&val=245\&title=Analysis $\% 20$ of\%20Production\%20Efficiency\%20of\%20Big\%20Red\%20Chili\%20and\%20Curly\%2 0Red\%20Chili\%20in\%20Central\%20Java\%20Province:\%20The\%20Stochastic\%20Prod uction\%20Frontier\%20Approach.

13. Sastraatmadja E. 2010. Suara Petani. Bandung. Masyarakat Geografi Indonesia.

14. Sesbany. 2011. Penguatan Kelembagaan Petani untuk Meningkatkan Posisi Tawar Petani [internet]. [diunduh 13 Januari 2019]. Tersedia dari: www.info.stppmedan.ac.id/pdf/jurnalsesbany1.pdf

15. Soekartawi, Rusmiadi, and Damaijati E. 1993. Risiko and Ketidakpastian dalam Agribisnis (Teori and Aplikasi). Raja Grafindo Persada. Jakarta.

16. Soekartawi. 2002. Analisis Usaha Tani. Jakarta: UI - Press. 